\title{
Interoceptive Effects of Alcohol Require mGlu5 Receptor Activity in the Nucleus Accumbens
}

\author{
Joyce Besheer, Julie J. M. Grondin, Michael C. Salling, Marina Spanos, Rebekah A. Stevenson, and Clyde W. Hodge \\ Bowles Center for Alcohol Studies, Department of Psychiatry, University of North Carolina at Chapel Hill, Chapel Hill, North Carolina 27599
}

The interoceptive effects of alcohol are major determinants of addiction liability. Metabotropic glutamate (mGlu) receptors are widely expressed in striatal circuits known to modulate drug-seeking. Given that the interoceptive effects of drugs can be important determinants of abuse liability, we hypothesized that striatal mGlu receptors modulate the interoceptive effects of alcohol. Using drug discrimination learning, rats were trained to discriminate alcohol $(1 \mathrm{~g} / \mathrm{kg}$, i.g. ) versus water. We found that systemic antagonism of metabotropic glutamate subtype 5 (mGlu5) receptors [10 mg/kg 2-methyl-6-(phenylethynyl)pyridine (MPEP) and $3 \mathrm{mg} / \mathrm{kg}$ 3-((2-methyl-1,3-thiazol-4yl)ethynyl)pyridine], but not mGlul receptors ([0.3-3 mg/kg JNJ16259685) (3,4-dihydro-2H-pyrano[2,3] $\beta$-quinolin-7-yl)(cis-4methoxycyclohexyl) methanone)], inhibited the discriminative stimulus effects of alcohol. Furthermore, mGlu5 receptor antagonism (10 $\mathrm{mg} / \mathrm{kg}$ MPEP) significantly inhibited neuronal activity in the nucleus accumbens core as levels of the transcription factor c-Fos were significantly reduced. Accordingly, targeted inhibition of mGlu5 receptors (20 $\mu \mathrm{g}$ of MPEP) in the nucleus accumbens core blunted the discriminative stimulus effects of alcohol $(1 \mathrm{~g} / \mathrm{kg})$. Anatomical specificity was confirmed by the lack of effect of inhibition of mGlu5 receptors (10-30 $\mu \mathrm{g}$ of MPEP) in the dorsomedial caudate-putamen and the similar cytological expression patterns and relative density of mGlu5 receptors between the brain regions. Functional involvement of intra-accumbens mGlu5 receptors was confirmed as activation of mGlu5 receptors [ $10 \mu \mathrm{g}$ of $(R S)$-2-amino-2-(2-chloro-5-hydroxyphenyl)acetic acid sodium salt enhanced the discriminative stimulus effects of a low alcohol dose ( $0.5 \mathrm{~g} / \mathrm{kg}$ ), and mGlu5 receptor inhibition (20 $\mu \mathrm{g}$ of MPEP) prevented the agonist-induced enhancement. These results show that mGlu5 receptor activity in the nucleus accumbens is required for the expression of the interoceptive effects of alcohol.

\section{Introduction}

Alcohol use is woven into the fabric of most societies with an estimated global population of 2 billion who drink alcohol and 76.3 million who develop diagnosable alcohol use disorders (World Health Organization, 2004). Prominent theories of addiction argue that alcohol and other drugs of abuse usurp brain reward systems, which include striatal circuits (Hyman et al., 2006) that evolved to regulate natural reward and survival (Schultz, 2000). In addition to reward and reinforcement processes, the interoceptive (subjective) effects of drugs represent a second major controlling process that regulates drug-seeking behavior. For example, the interoceptive effects of drugs can promote drug-seeking (Wise et al., 2008) and can interact with or supplement positive reinforcing effects by providing drug-specific qualitative and quantitative feedback to the organism (Stolerman, 1992). Thus, delineating the neural mechanisms of the interoceptive effects of alcohol and other drugs is critical to understanding how these substances gain control over behavioral functions in addiction.

For decades, the drug discrimination procedure has been used in both humans and animals as a compelling measure of the

\footnotetext{
Received May 20, 2009; revised June 17, 2009; accepted June 17, 2009.

This work was supported in part by National Institutes of Health Grants AA016009 (J.B.) and AA014983 (C.W.H.) and by the Bowles Center for Alcohol Studies.

Correspondence should be addressed to Dr. Joyce Besheer, Bowles Center for Alcohol Studies, Thurston-Bowles Building, CB \#7178, University of North Carolina at Chapel Hill, Chapel Hill, NC 27599. E-mail: jbesheer@med.unc.edu.

D0I:10.1523/JNEUROSCI.2366-09.2009

Copyright $\odot 2009$ Society for Neuroscience $\quad$ 0270-6474/09/299582-10\$15.00/0
}

interoceptive effects of drugs (Kelly et al., 1997); however, the mechanisms that regulate how the brain perceives alcohol remain to be fully characterized. Although there is a well established role for ionotropic glutamate receptors and related brain circuitry in modulating the interoceptive effects of alcohol (Grant et al., 1991; Hodge and Cox, 1998), the role of metabotropic glutamate $(\mathrm{mGlu})$ receptor activity in striatal circuits is unknown. This point is especially relevant given that mGlu (mGlu1, mGlu5, and mGlu2/3) receptors regulate alcohol selfadministration and relapse-like behavior (Bäckström et al., 2004; Bäckström and Hyytiä, 2005; Cowen et al., 2005; Schroeder et al., 2005, 2008; Hodge et al., 2006; Lominac et al., 2006; Rodd et al., 2006; Cowen et al., 2007; Besheer et al., 2008b). Furthermore, mGlu receptor activity in the nucleus accumbens regulates cocaine and heroin-seeking behaviors (Bossert et al., 2006; Peters and Kalivas, 2006; Kumaresan et al., 2009) and is required for drug-induced changes in synaptic plasticity (Robbe et al., 2003). As such, mGlu receptors are rapidly emerging as potential therapeutic targets for alcoholism and other addictions (Heilig and Egli, 2006).

Given that information about the interoceptive effects of a drug may interact with its positive reinforcing properties and that mGlu receptors are densely expressed within striatal regions known to modulate alcohol-seeking behavior (Ferraguti and Shigemoto, 2006), we hypothesized that striatal mGlu receptors regulate the discriminative stimulus effects of alcohol. To address this hypothesis, we used a well characterized drug discrimination procedure to train rats to discriminate the interoceptive effects of 
a moderate dose of alcohol ( $1 \mathrm{~g} / \mathrm{kg}$, i.g.) from water (intragastric gavage). Preliminary work has shown that systemic antagonism of mGlu5 receptors inhibits the GABAergic component of the discriminative stimulus effects of alcohol (Besheer and Hodge, 2005). To extend this work, we first asked whether inhibition of glutamate neurotransmission by systemic pharmacological blockade of group I mGlu receptors produces discriminative stimulus effects that generalize to alcohol. Next, we examined whether mGlu receptors modulate the discriminative stimulus effects of alcohol. Using immunohistochemical techniques to evaluate c-Fos immunoreactivity (IR), we next determined whether mGlu5 receptor inhibition is associated with changes in neuronal activity in the striatum. Finally, guided by the anatomical and pharmacological specificity of the results, we sought to determine whether mGlu5 receptors in the nucleus accumbens core functionally regulate the discriminative stimulus effects of alcohol.

\section{Materials and Methods}

\section{Animals}

For the discrimination training experiments, male Long-Evans rats (Harlan Sprague Dawley) weighing 150-200 g on arrival to the colony were individually housed in Plexiglas cages. Rats were handled and weighed daily for 2 weeks before lever press training began. Rats were fed $\sim 16$ g of food daily for the duration of the study such that weights were maintained at $\sim 325 \mathrm{~g}$. Water was available continuously in the home cage. The colony room was maintained on a $12 \mathrm{~h}$ light/dark cycle, and experiments were conducted during the light portion of the cycle. Animals were under continuous care and monitoring by veterinary staff from the Division of Laboratory Animal Medicine at University of North Carolina-Chapel Hill. All procedures were also performed in accordance with the National Institutes of Health Guide to Care and Use of Laboratory Animals and institutional guidelines.

\section{Apparatus}

Operant chambers (Med Associates) measuring $31 \times 32 \times 24 \mathrm{~cm}$ were located within sound-attenuating cubicles and equipped with an exhaust fan that provided ventilation and masked external sounds. Two response levers were located on the right wall of each chamber. Responses on the levers activated a liquid dipper centered between the levers that presented a $10 \%$ sucrose $(\mathrm{w} / \mathrm{v})$ solution in a $0.1 \mathrm{ml}$ dipper cup for $4 \mathrm{~s}$ during each operation. A stimulus light was located above each response lever and was activated each time a reinforcer was delivered. The chambers were illuminated by an $8 \mathrm{~W}$ light and were interfaced (Med Associates) to a computer programmed to control sessions and record data.

\section{Alcohol discrimination training and testing procedures}

Rats were trained to lever press on a fixed-ratio 1 (FR1) schedule of reinforcement. The presentation of the right and left lever was alternated each day, and the schedule of reinforcement was gradually increased to FR10. Discrimination training began once responding on the FR10 schedule was stable ( $<10 \%$ daily variation in total number of responses).

Discrimination training. Training sessions were conducted $5 \mathrm{~d}$ /week (Monday through Friday) during which alcohol $(1 \mathrm{~g} / \mathrm{kg})$ or water was administered by intragastric gavage before the start of the sessions. Immediately after the alcohol or water administration, the rats were placed in the chambers, and, after a $10 \mathrm{~min}$ delay, the house light was illuminated and both levers were introduced into the chamber signaling the beginning of the $15 \mathrm{~min}$ session. The lever associated with alcohol or water administration was randomly assigned and counterbalanced across animals. After alcohol administration, completion of 10 responses on the alcohol-appropriate lever resulted in the presentation of the sucrose solution. Similarly, after water administration, completion of 10 responses on the water-appropriate lever resulted in sucrose delivery. During both alcohol and water sessions, responses on the inappropriate lever were recorded but produced no programmed consequences. Water and alcohol training days varied on a double alternation schedule $(\mathrm{W}, \mathrm{W}$, A, A...). The training sessions continued until the percentage of alcohol- and water-appropriate lever press responses emitted before the first reinforcer and during the entire session was $>80 \%$ for 8 of 10 consecutive days. Once these criteria were met, testing began.

Testing. Test sessions were identical to the training sessions except that they were $2 \mathrm{~min}$ in duration (after the $10 \mathrm{~min}$ delay), and completion of an FR10 on either lever resulted in sucrose delivery. Reinforcement was delivered during test sessions to assess the possible effects of test treatments on overall response rates. These test sessions were interspersed with training sessions only if performance during three of the previous four training sessions met the accuracy criteria. For all rats, an alcohol substitution curve was determined before testing of the mGlu receptor compounds to ensure adequate alcohol stimulus control. Cumulative dosing procedures (Hiltunen and Järbe, 1989) were used for all the testing sessions, with the exception of the microinjection studies. For example, to determine a cumulative alcohol dose curve $(0.1,0.3,1.0$, and 1.7 $\mathrm{g} / \mathrm{kg}$ ), rats initially received $0.1 \mathrm{~g} / \mathrm{kg}$ alcohol and were placed in the chamber for a testing session. At the conclusion of the session, the rats received a subsequent alcohol administration of $0.2 \mathrm{~g} / \mathrm{kg}$ and another test session. This procedure was repeated with two subsequent administrations of 0.7 $\mathrm{g} / \mathrm{kg}$ alcohol, which are additive to produce the stated dose range. Thus, testing of the entire dose curve was completed in $\sim 48 \mathrm{~min}$. Testing occurred no more than twice per week.

\section{Surgery and microinjection procedures}

Surgery. Discrimination-trained rats were anesthetized with an isoflurane/oxygen combination, and 26 gauge guide cannulae (Plastics One) were implanted bilaterally to terminate $2 \mathrm{~mm}$ above the nucleus accumbens core or the dorsomedial caudate-putamen. The coordinates for the nucleus accumbens and caudate were anteroposterior (AP) +1.7 , mediolateral $(\mathrm{ML})+1.5 \mathrm{~mm}$, dorsoventral $(\mathrm{DV})-5.5 \mathrm{~mm}$; and $\mathrm{AP}+1.7$ $\mathrm{mm}, \mathrm{ML}+1.5 \mathrm{~mm}, \mathrm{DV}-2.4 \mathrm{~mm}$, respectively (Paxinos and Watson, 1998). All rats were allowed to recover for at least 1 week before resuming alcohol discrimination training.

Drug administration. Injections were made with Hamilton syringes connected to 33 gauge injectors (Plastics One) that extended $2 \mathrm{~mm}$ below the guide cannulae. A pump (model 22; Harvard Apparatus) was used to deliver a volume of $0.5 \mu \mathrm{l}$ into each side over $1 \mathrm{~min}$; the injectors were left in place for another $1.5 \mathrm{~min}$ after the injections to allow for diffusion. Rats were then administered a single alcohol dose and placed in the chambers for a test session.

Cannulae verification. Once the experiment was complete, rats were deeply anesthetized with pentobarbital and perfused transcardially with 0.1 M PBS, followed by $4 \%$ formaldehyde, $\mathrm{pH}$ 7.4. Brains were extracted, sliced into $40 \mu \mathrm{m}$ coronal sections, and stained with cresyl violet. Cannulae placement was verified using an Olympus CX41 light microscope (Olympus America) and only the data from rats with cannulae determined to be in the target brain regions were used in the analyses. For the 2-methyl-6-(phenylethynyl)-pyridine (MPEP) study (experiment 3), one rat from each of the groups (nucleus accumbens and dorsomedial caudate) had an incorrect placement (data not shown) and is not included in any of the data. Anatomical location is shown in Figure 4, $a$ and $b$. For the (RS)-2-amino-2-(2-chloro-5-hydroxyphenyl)acetic acid sodium salt (CHPG)/MPEP study (experiment 5), two rats had incorrect placements, and one rat had an infection. Data from these rats were not included in the analyses and are not illustrated in Figure $5 c$.

\section{Immunohistochemistry procedures}

c-Fos. Free-floating sections were blocked in PBS/0.1\% Triton X-100/ $10 \%$ goat serum and then incubated in PBS/0.1\% Triton X-100/3\% goat serum and rabbit anti-c-Fos antibody (1:20,000 dilution; Calbiochem) for $48 \mathrm{~h}$ at $4^{\circ} \mathrm{C}$ with agitation. Western blot analysis from previous characterization indicated that the antibody recognizes $55 \mathrm{kDa}$ c-Fos and 62 $\mathrm{kDa}$ c-Fos proteins and does not cross-react with the $39 \mathrm{kDa}$ Jun proteins (the technical information of the manufacturer). Sections were then washed in PBS, incubated for $1 \mathrm{~h}$ in a solution of biotinylated secondary anti-rabbit antibody, and then rinsed in PBS. Sections were next processed with avidin-biotin complex (Vector ABC kit; Vector Laboratories), and Fos-IR was visualized using a diaminobenzidine solution (Polysciences) containing $0.006 \%$ hydrogen peroxide, $0.005 \%$ cobalt, and $0.0075 \%$ nickel. For consistency of staining across subjects, brain tissue was processed simultaneously. 
$m$ Glu5 receptor. Endogenous peroxidase was blocked by incubating the free-floating sections in $1 \%$ hydrogen peroxide for $5 \mathrm{~min}$, followed by citra buffer antigen retrieval performed at $70^{\circ} \mathrm{C}$ for $30 \mathrm{~min}$ (Antigen Retrieval Citra; BioGenex). Sections were blocked in PBS/0.1\%Triton $\mathrm{X}-100 / 10 \%$ goat serum for $1 \mathrm{~h}$ and then incubated in PBS/0.1\% Triton $\mathrm{X}-100 / 3 \%$ goat serum and rabbit anti-mGlu5 receptor (1:3000; Upstate Biotechnology). This antibody stains a single band of $125 \mathrm{kDa}$ molecular weight on Western blot (the technical information of the manufacturer). Sections were then incubated in secondary antibody for $1 \mathrm{~h}$ using the Dako EnVision kit. Immunoreactivity was detected with nickelenhanced diaminobenzidine (Dako EnVision Kit) as a chromagen. Sections were then counterstained with toluidine blue, mounted, dried, and coverslipped with Cytoseal. For consistency of staining across subjects, brain tissue was processed simultaneously.

\section{Immunohistochemical quantification}

c-Fos and mGlu5 receptor immunoreactivity was visualized using an Olympus CX41 light microscope (Olympus America). Images were acquired using a digital camera (Regita model; QImaging) interfaced to a desktop computer (Dell Computer Company). Image analysis software (Bioquant Nova Advanced Image Analysis; R \& M Biometric) was used to quantify immunoreactivity. The microscope, camera, and software were background corrected and normalized to preset light levels to ensure fidelity of data acquisition. For Fos immunoreactivity, cell count measurements were calculated from a circumscribed field (e.g., brain region), divided by the area of the region, and expressed as Fos-positive cells per square millimeter. mGlu5 receptor immunoreactivity was quantified as pixel density per square millimeter. Analysis was conducted by a researcher blind to treatment conditions. Data were acquired from a minimum of three sections per brain region per animal for the Fos-immunoreactivity analyses and two sections per brain region per animal for the mGlu5 receptor immunoreactivity analyses; the data were then averaged to obtain a single value per subject. The brain regions examined for the Fos analyses were the nucleus accumbens (shell and core) and the caudateputamen (dorsomedial and ventral), and for the mGlu5 receptor analyses the nucleus accumbens (core) and the caudate-putamen (dorsomedial) were all analyzed at AP 1.7-1.0 mm (see Fig. 3a).

\section{Western blot analysis}

Rats were anesthetized using isoflurane and decapitated. Brains were rapidly removed and frozen in isopentane at $-40^{\circ} \mathrm{C}$ and stored at $-80^{\circ} \mathrm{C}$. Frozen brains were sectioned coronally into $1 \mathrm{~mm}$ sections using a cryostat at $-15^{\circ} \mathrm{C}$ (Leica), and 1.25 -mm-diameter punches were taken from the nucleus accumbens core and dorsomedial caudate-putamen using a punch tool (Stoelting) and submerged in buffer $(100 \mu \mathrm{l}: 8 \mathrm{mmol} / \mathrm{L}$ $\mathrm{NaH}_{2} \mathrm{PO}_{4}$ monobasic, $0.5 \mathrm{mmol} / \mathrm{L} \mathrm{NaH}_{2} \mathrm{PO}_{4}$ dibasic, $147 \mathrm{mmol} / \mathrm{L} \mathrm{NaCl}$, 1:100 protease, and phosphatase 1 and 2 inhibitor cocktails). Tissue was homogenized via sonication (Branson Sonifier), and protein concentration was measured using a calorimetric assay kit (Pierce). Protein $(10 \mu \mathrm{g})$ was diluted 4:1 with lithium dodecyl sulfate sample buffer $(40-70 \%$ glycerol), 10:1 with sample reducing agent, vortexed, loaded onto a NuPage 4-12\% Bis-Tris polyacrylamide gel (Invitrogen) for gel electrophoresis separation, and transferred to nitrocellulose membrane using an iBlot dry blotting system (Invitrogen). Membranes were blocked with 3\% albumin bovine serum (Sigma) before being incubated with primary antibodies [rabbit anti-mGlu5 receptor (1:1000; Upstate Biotechnology) in blocking solution $4^{\circ} \mathrm{C}$ overnight and $\beta$-actin (mouse monoclonal, 1:5000; Sigma) in blocking solution $1 \mathrm{~h}$ at room temperature] and washed before incubation with secondary antibodies (HRP-conjugated goat anti-rabbit and goat antimouse, 1:10,000; Jackson ImmunoResearch). Membranes were then visualized using enhanced chemiluminescence substrate (Pierce), and bands were quantified using optical density measurements (NIH/Scion Image). Data were converted to percentage of $\beta$-actin for each blot.

Experiment 1: effects of $m G l u$ receptor compounds alone and on the discriminative stimulus effects of alcohol

Systemic antagonist substitution. To determine whether the mGlu receptor compounds produced alcohol-like interoceptive effects, cumulative dose ranges of the mGlul receptor antagonist (3,4-dihydro- $2 H$-pyrano[2,3] $\beta$ - quinolin-7-yl)(cis-4-methoxycyclohexyl) methanone (JNJ16259685) $(0.3-10 \mathrm{mg} / \mathrm{kg}$, i.p.) and the mGlu5 receptor antagonist MPEP (1-30 $\mathrm{mg} / \mathrm{kg}$, i.p.) were tested; water/alcohol administration was withheld during these tests.

Systemic $m$ Glu receptor modulation of the discriminative stimulus effects of alcohol. To determine whether the mGlu receptor compounds altered the interoceptive effects of alcohol, the compounds [JNJ16259685, 0-3 $\mathrm{mg} / \mathrm{kg}$, i.p.; MPEP, 0-10 mg/kg, i.p.; 3-((2-methyl-1,3-thiazol-4yl)ethynyl)pyridine (MTEP), $0-3 \mathrm{mg} / \mathrm{kg}$, i.p.] were administered $10 \mathrm{~min}$ before the first alcohol dose of the cumulative alcohol substitution test. The antagonists tested demonstrate peak and stable receptor occupancy for at least the first hour after administration (Anderson et al., 2003; Lavreysen et al., 2004) and, as such, appear suitable for testing using the 48 min cumulative dosing procedures. Dose order testing of the mGlu receptor compounds was randomized.

\section{Experiment 2: effects of $m G l u 5$ receptor antagonism on striatal c-Fos immunoreactivity}

Male Long-Evans rats (mean \pm SEM, $358.5 \pm 5.7$ g; Harlan Sprague Dawley) were habituated to handling for $5 \mathrm{~d}$. A day before the test, rats were administered saline (intraperitoneally). On the test day, rats were administered saline (intraperitoneally) or MPEP (10 mg/kg, i.p.). Approximately $110 \mathrm{~min}$ after the saline or MPEP administration, rats were deeply anesthetized with pentobarbital and perfused with $0.1 \mathrm{M}$ PBS, followed by $4 \%$ paraformaldehyde, $4^{\circ} \mathrm{C}, \mathrm{pH}$ 7.4. The brains were removed from the skull and placed in the same fixative solution for $\sim 24 \mathrm{~h}$ before being washed with PBS and sliced coronally on a vibratome into $40 \mu \mathrm{m}$ sections. Tissue was stored $\left(-20^{\circ} \mathrm{C}\right)$ in cryoprotectant until immunohistochemistry processing.

\section{Experiment 3: effects of intrastriatal mGlu5 receptor antagonism} on the discriminative stimulus effects of alcohol

MPEP was microinfused into the nucleus accumbens $(0-20 \mu \mathrm{g} / 0.5 \mu \mathrm{l}$ per side) or the dorsomedial caudate $(0-30 \mu \mathrm{g} / 0.5 \mu \mathrm{l}$ per side). After the diffusion period, rats received a single alcohol dose ( $1 \mathrm{~g} / \mathrm{kg}$, i.g.) and were placed in the chamber for a test session. Test sessions were identical in parameters to the cumulative dosing test sessions, with the exception that rats experienced a single test. A single MPEP and alcohol dose was tested in random order during each session.

\section{Experiment 4: assessment of $m G l u 5$ receptor expression in the} nucleus accumbens and dorsomedial caudate

To establish whether mGlu5 receptors are similarly expressed in the nucleus accumbens and the dorsomedial caudate, brain tissue from the two regions was evaluated using mGlu5 receptor immunoreactivity and Western blot analysis. Tissue from the saline-treated rats in the c-Fos mapping study was used for analysis of mGlu 5 receptor immunoreactivity. Tissue from male Long-Evans rats (mean \pm SEM, $360 \pm 4.6 \mathrm{~g} ; n=4$; Harlan Sprague Dawley) was used for the analysis of mGlu5 receptor protein expression using Western blot analysis.

\section{Experiment 5: effects of intra-accumbens $m$ Glu5 receptor}

activation on the discriminative stimulus effects of alcohol

The mGlu5 receptor agonist CHPG was microinfused into the nucleus accumbens ( 0 or $10 \mu \mathrm{g} / 0.5 \mu \mathrm{l}$ per side). After the $1.5 \mathrm{~min}$ diffusion period, rats received a single alcohol dose $(0.5 \mathrm{~g} / \mathrm{kg}$, i.g. $)$ and were placed in the chamber for a test session. To assess whether mGlu5 receptor antagonism could inhibit the mGlu5 receptor agonist-induced effects, MPEP was first microinfused into the nucleus accumbens $(10 \mu \mathrm{g} / 0.5 \mu \mathrm{l}$ per side). Five min after the end of the diffusion period, CHPG $(10 \mu \mathrm{g} / 0.5$ $\mu \mathrm{l}$ per side) was microinfused into the nucleus accumbens. After the diffusion period, rats received a single alcohol dose $(0.5 \mathrm{~g} / \mathrm{kg}$, i.g. $)$ and were placed in the chamber for a test session. Rats received another test in which CHPG (0 or $10 \mu \mathrm{g} / 0.5 \mu \mathrm{l}$ per side) was microinfused into the nucleus accumbens core before a low alcohol dose ( $0.3 \mathrm{~g} / \mathrm{kg}$, i.g.).

\section{Drugs}

For intragastric gavage administration, ethanol ( $95 \% \mathrm{w} / \mathrm{v})$ was diluted in distilled water to a concentration of $20 \%(\mathrm{v} / \mathrm{v})$ and administered in var- 
a
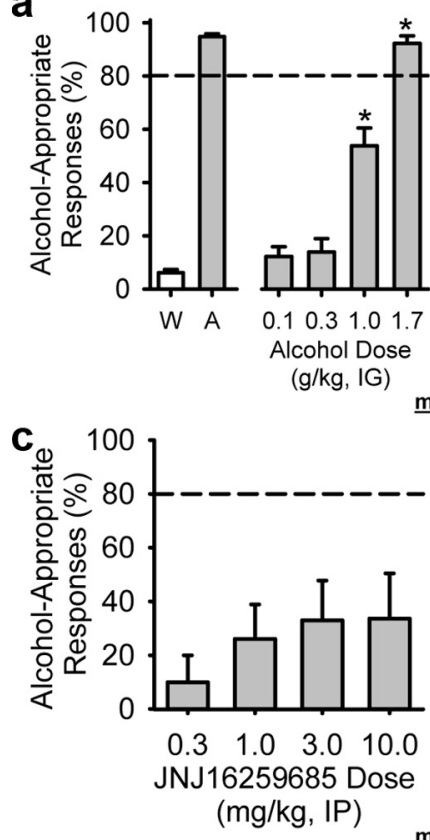

mGlu1 receptors
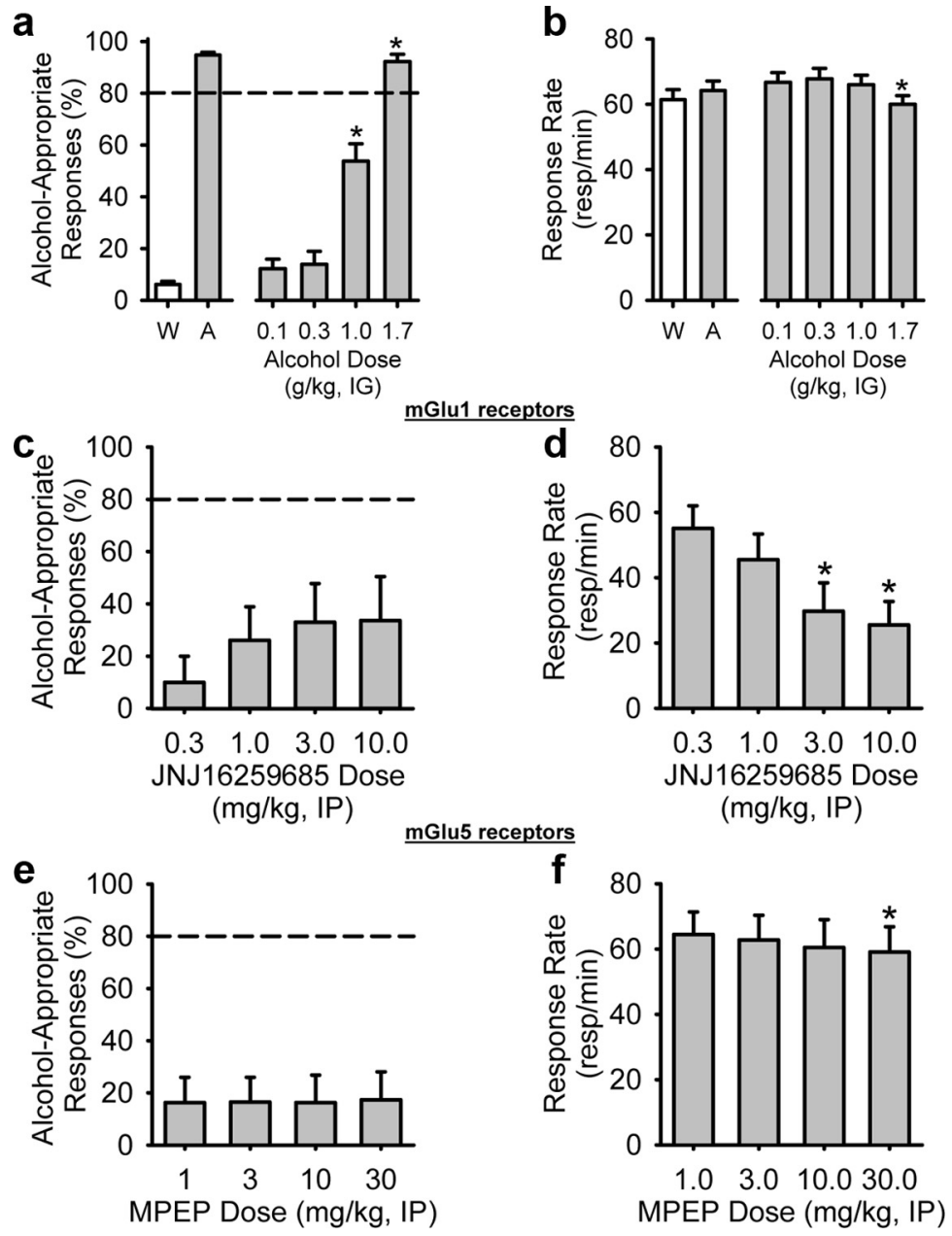

Figure 1. mGlu receptor compounds do not produce alcohol-like interoceptive effects when tested alone in the absence of alcohol. $\boldsymbol{a}$, Before testing of the $\mathrm{mGlu}$ receptor compounds, alcohol stimulus control was confirmed in all rats by determination of an alcohol substitution curve. The percentage of alcohol-appropriate lever responses $(\boldsymbol{a})$ and response rate $(\boldsymbol{b})$ during the water (W) and alcohol (A) training session that preceded testing of the cumulative alcohol curve are shown to the left of the axis break (not included in the analyses). Dose-dependent substitution for the $1 \mathrm{~g} / \mathrm{kg}$ alcohol training dose was observed, indicating that the procedures established reliable stimulus control; $\boldsymbol{b}$, a reduction in response rate was observed at the highest alcohol dose (1.7 $\mathrm{g} / \mathrm{kg}$ ). c, Antagonism of mGlu1 (JNJ16259685, intraperitoneally; $n=10$ ) or mGlu5 (MPEP, intraperitoneally; $n=10)(\boldsymbol{e})$ receptors did not produce alcohol-like properties, although reductions in response rate $(\boldsymbol{d}, \boldsymbol{f})$ indicate that the compounds were behaviorally active. Horizontal dashed line $(>80 \%)$ represents full expression of the discriminative stimulus effects of alcohol. ${ }^{*} p<0.05$, significant difference from $0.1 \mathrm{~g} / \mathrm{kg}$ alcohol (Tukey's test). Values on graphs represent mean \pm SEM.

of MPEP at mGlu4 receptors in BHK cells, and MPEP has also been shown to blunt NMDAevoked currents (O'Leary et al., 2000). MTEP is a potent systemically active noncompetitive mGlu5 receptor antagonist (Anderson et al., 2003; Cosford et al., 2003); affinities ( $K_{\mathrm{i}}$ values) of MPEP and MTEP at rat $m$ Glu5 receptors are 12 and $16 \mathrm{~nm}$, respectively (Cosford et al., 2003). CHPG selectively activates mGlu5 receptors, not mGlul receptors, but has been shown to potentiate NMDA function in vitro (Doherty et al., 1997).

\section{Data analysis}

For the behavioral experiments, response accuracy was expressed as the percentage of alcohol-appropriate lever presses during delivery of the first reinforcer. Response rate (responses per minute) was analyzed for the entire session and provided an index of locomotor ability. Complete expression of the discriminative stimulus effects of alcohol (i.e., full substitution) was defined as $>80 \%$ choice of the alcohol lever on completion of the first FR10 during test sessions. If an animal did not complete an FR10 during these test sessions, then data from that animal was not included in the response accuracy analysis but were included in the response rate analysis. Oneor two-way repeated measures ANOVA were used to analyze response accuracy and response rate data. Response accuracy data were subjected to arcsine transformation to normalize the distribution of the percentage scores (Stolerman and Olufsen, 2000). Fos-IR, mGlu5 receptor expression, and IR were analyzed using one-way ANOVA. Tukey's post hoc analyses were used to explore significant interactions. Significance was declared at $p \leq 0.05$.

\section{Results}

\section{Confirmation of discriminative stimulus control}

To ensure adequate alcohol stimulus control, a cumulative alcohol substitution curve was determined for all rats before testing of the mGlu receptor compounds began. Alcohol-appropriate responding increased as a function of al-

ious volumes to obtain cumulative doses of $0.1,0.3,1.0$, and $1.7 \mathrm{~g} / \mathrm{kg}$. A corresponding volume of water to the $1 \mathrm{~g} / \mathrm{kg}$ alcohol training dose was used for water intragastric gavage administration. MPEP (SigmaAldrich) was dissolved in saline (vehicle) for systemic administration and in artificial CSF (aCSF) for microinfusions. MTEP (Ascent Scientific) was dissolved in saline (vehicle). JNJ16259685 (Tocris Biosciences) was suspended in $0.1 \%$ carboxymethocellulose (vehicle). All compounds were injected intraperitoneally at a volume of $1 \mathrm{ml} / \mathrm{kg}$. CHPG (Ascent Scientific) was dissolved in aCSF for microinfusions.

MPEP is a systemically active noncompetitive mGlu5 receptor antagonist that shows at least 1000 -fold greater specificity for mGlu5 than mGlu1 receptors (Gasparini et al., 1999). JNJ16259685 is a systemically active potent noncompetitive mGlul receptor antagonist that displays $>1000$-fold selectivity over mGlu5 receptors in a $\mathrm{Ca}^{2+}$ mobilization assay (Lavreysen et al., 2004). MPEP and JNJ16259685 also display no agonist, antagonist, or allosteric activity at mGlu2, mGlu3, or mGlu6 receptors (Gasparini et al., 1999; Lavreysen et al., 2004), and importantly mGlu5 receptor-deficient mice show no binding of MPEP (Anderson et al., 2003). However, Mathiesen et al. (2003) has shown agonist-like activity cohol test dose (Fig. $1 a)\left(F_{(3,111)}=71.10, p<0.001\right)$, with 1.7 $\mathrm{g} / \mathrm{kg}$ resulting in full substitution $(>80 \%)$ for the alcohol training dose (i.e., produced discriminative stimulus effects similar to the training dose). The $1.0 \mathrm{~g} / \mathrm{kg}$ alcohol dose (i.e., training dose), which generally produces $>90 \%$ alcoholappropriate responding during regular training sessions (Fig. $1 a$, left of axis break), tends to produce $\sim 60 \%$ alcoholappropriate responding under the cumulative dosing procedure (Hodge et al., 2001b). A slight decrease in response rate was observed at the highest alcohol dose $\left(1.7 \mathrm{~g} / \mathrm{kg} ; F_{(3,111)}=\right.$ 4.63, $p=0.004$ ) (Fig. 1b).

Experiment 1: effects of $m G l u$ receptor compounds alone and on the discriminative stimulus effects of alcohol

We first asked whether inhibition of glutamate neurotransmission by pharmacological blockade of group I mGlu receptors 
(i.e., mGlu1 and mGlu5 receptor antagonists) produces discriminative stimulus effects that generalize to alcohol. The group I mGlu receptor antagonists did not produce alcohol-like properties (i.e., $<40 \%$ alcohol-appropriate responding) (Fig. 1c,e); however, significant reductions in response rate (Fig. $1 d$ : JNJ16259685, $F_{(3,27)}=8.44, p<0.001$; Fig. 1f: $\left.\operatorname{MPEP}, F_{(3,29)}=3.83, p=0.02\right)$ were observed, indicating that the compounds were biologically active at the tested doses and pretreatment time intervals.

To test the extent to which mGlu receptors modulate the discriminative stimulus effects of alcohol, rats received pretreatment administration of the mGlu receptor compounds before alcohol (cumulative doses, $0.1-1.7 \mathrm{~g} / \mathrm{kg}$, i.g.) administration. The mGlul receptor antagonist JNJ16259685 did not alter the discriminative stimulus effects of alcohol (Fig. 2a) but produced motor reductions as indicated by a significant main effect of JNJ16259685 dose $\left(F_{(3,27)}=3.63, p=\right.$ 0.03 ) (Fig. $2 b$ ), again indicating that the compound was biologically active at the tested doses and pretreatment time interval. In contrast, mGlu5 receptor antagonism by MPEP blocked the discriminative stimulus effects of 1 and $1.7 \mathrm{~g} / \mathrm{kg}$ alcohol (Fig. 2c) (alcohol dose, $F_{(3,30)}=27.91, p<$ 0.001; MPEP dose, $F_{(3,30)}=5.66, p=0.003$; interaction, $\left.F_{(9,90)}=1.97, p=0.05\right)$, resulting in alcohol-appropriate responding at a level that would be expected by chance alone on a two-lever task (i.e., 50\%). A significant response rate reduction was observed by MPEP pretreatment as indicated by a significant main effect of MPEP dose $\left(F_{(3,30)}=4.77, p=0.008\right)$ and a significant interaction $\left(F_{(9,90)}=\right.$ $2.89, p=0.005)$; however, the reduction in the discriminative stimulus effects of alcohol occurred at a dose that did not produce nonspecific motor reductions (Fig. $2 d$ ). To confirm the specificity of mGlu5 receptor function in altering the discriminative stimulus effects of alcohol, we examined another mGlu5 receptor antagonist, MTEP. MTEP pretreatment inhibited the discriminative stimulus effects of $1.7 \mathrm{~g} / \mathrm{kg}$ alcohol to an equal degree as MPEP by a dose of 3 $\mathrm{mg} / \mathrm{kg}$ (Fig. $2 e$ ) (alcohol dose, $F_{(3,24)}=10.14, p<0.001$; MTEP dose, $F_{(2,16)}=4.09, p=0.04$; interaction, $\left.F_{(6,48)}=2.61, p=0.03\right)$. MTEP pretreatment resulted in nonspecific changes (both increases and decreases) in response rates as indicated by a significant main effect of MTEP dose $\left(F_{(2,16)}=49.1, p=0.02\right)$ and a significant interaction $\left(F_{(6,48)}=6.81, p<0.001\right)$ (Fig. $2 f)$; however, the reduction in the discriminative stimulus effects of alcohol was not accompanied by a change in response rate. Given that the results from the MTEP assessment confirmed that the inhibition of the discriminative stimulus effects of alcohol were specific to mGlu5 receptor antagonism and not attributable to any possible off-target effects of MPEP,
MPEP was used as the mGlu5 receptor antagonist for the remainder of the study.

\section{Experiment 2: effects of mGlu5 receptor antagonism on striatal c-Fos immunoreactivity}

To determine whether mGlu5 receptor inhibition is associated with changes in neuronal activity in the striatum, we examined Fos-IR in subnuclei of the striatum (Fig. $3 a$ ) after systemic administration of the mGlu5 receptor antagonist MPEP. Results showed that MPEP produced a significant (2.7-fold) reduction in Fos-IR in the nucleus accumbens core (Fig. $3 b-d)\left(F_{(1,7)}=25.09, p=0.002\right)$. In contrast, neural activity in the nucleus accumbens shell and dorsomedial and lateral caudate-putamen was not altered by mGlu5 inhibition (Fig. $3 b, e, f)$. These data suggest that systemic inhibition of mGlu5 receptors is associated with inhibition of neural activity in the core of the nucleus accumbens. 
a

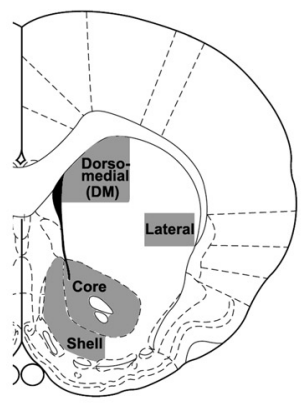

b
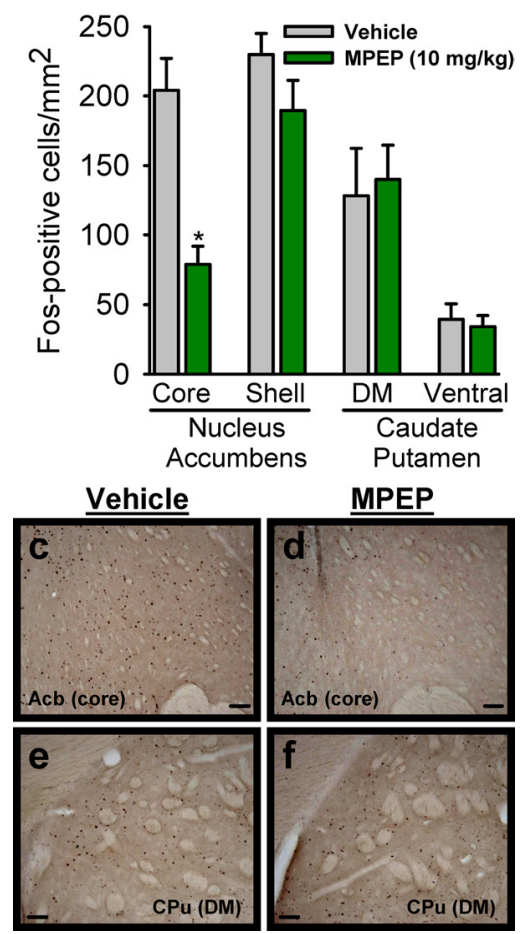

Figure 3. Neural activity in the nucleus accumbens core is significantly reduced by mGlu5 receptor antagonism. $\boldsymbol{a}$, Illustration of quantified areas. $\boldsymbol{b}$, Antagonism of $\mathrm{mGlu} 5$ receptors by $\operatorname{MPEP}(10 \mathrm{mg} / \mathrm{kg}$, i.p.) significantly reduced the number of Fos-positive cells ( $n=5$ per group) in the nucleus accumbens core. The other surveyed regions were not altered by MPEP pretreatment. $\mathbf{c}-\boldsymbol{f}$, Representative photomicrographs $(10 \times)$ of Fos-IR in the nucleus accumbens [Acb (core)] and the dorsomedial caudate-putamen [CPu (DM)] after vehicle or MPEP. Scale bars, 50 $\mu \mathrm{m} .{ }^{*} p<0.05$, significant difference from vehicle (Tukey's test). Values on graphs represent mean \pm SEM.

\section{Experiments 3 and 4: effects of intrastriatal mGlu5 receptor} antagonism on the discriminative stimulus effects of alcohol Guided by the anatomical specificity of the c-Fos immunoreactivity results, we sought to determine whether mGlu5 receptors in the nucleus accumbens core functionally regulate the discriminative stimulus effects of alcohol. Microinfusion of the mGlu5 receptor antagonist MPEP in the nucleus accumbens core blocked the discriminative stimulus effects of alcohol $\left(1 \mathrm{~g} / \mathrm{kg}\right.$, i.g.; $\left.F_{(2,12)}=6.82, p=0.01\right)$ (Fig. $\left.4 a\right)$, establishing a mechanistic role for intra-accumbens mGlu5 receptor activity. Response rate was unaffected by MPEP administration because neither dose differed from vehicle (Fig. 4a). To assess the functional and neuroanatomical specificity of mGlu5 receptor activity in the nucleus accumbens, we next evaluated the effects of MPEP in the dorsomedial caudate-putamen. In this brain region, mGlu5 antagonism did not alter the discriminative stimulus effects of alcohol even when a higher MPEP dose range was tested (Fig. $4 b)\left(F_{(3,20)}=2.07, p=0.14\right)$, and response rate was unaffected by MPEP pretreatment (Fig. 4b). To verify sensitivity and function of mGlu5 receptors in the dorsomedial caudate-putamen, we tested a higher alcohol dose $(1.7 \mathrm{~g} / \mathrm{kg}$, i.g. $)$ in combination with MPEP $(30 \mu \mathrm{g})$ and found only nonspecific reductions in motor activity [i.e., response rate (responses per minute) reduced from $64.1 \pm 4.9$ to $55.5 \pm 5.4 ; t_{(7)}=2.50, p=$ 0.04 ], with no effect on the discriminative stimulus effects of alcohol.

Examination of mGlu5 receptor immunoreactivity (Fig. $4 c$ ) and protein expression (Fig. $4 d$ ) confirmed that differential brain region involvement in the discriminative stimulus effects of alcohol was not attributable to differences in cytological expression pattern, or relative density, of mGlu5 receptors in the nucleus accumbens core or the dorsomedial caudate-putamen.

\section{Experiment 5: effects of intra-accumbens mGlu5 receptor activation on the discriminative stimulus effects of alcohol} To further establish functional involvement of mGlu5 receptor activity in the discriminative stimulus effects of alcohol, we next examined whether activation of mGlu5 receptors could potentiate the discriminative stimulus effects of a low alcohol dose $(0.5$ $\mathrm{g} / \mathrm{kg}$ ). A one-way repeated measures ANOVA showed that microinfusion of the mGlu5 receptor agonist CHPG in the nucleus accumbens core potentiated the discriminative stimulus effects of alcohol ( $0.5 \mathrm{~g} / \mathrm{kg}$, i.g.) (Fig. $5 a)$, and antagonism of mGlu5 receptors by intra-accumbens MPEP pretreatment prevented the agonist-induced potentiation of the discriminative stimulus effects of alcohol $\left(0.5 \mathrm{~g} / \mathrm{kg}\right.$, i.g.; $\left.F_{(2,14)}=8.65, p=0.004\right)$ (Fig. $\left.5 a\right)$. Response rate was unaffected by CHPG or MPEP pretreatment (Fig. 5b). Interestingly, the two rats that were excluded from the study as a result of incorrect cannulae placement showed no change in behavior after CHPG treatment or combined MPEP and CHPG treatment. Furthermore, there was a trend for a CHPG $(10 \mu \mathrm{g})$-induced enhancement of a low alcohol dose ( 0.3 g/kg, i.g.; alcohol-appropriate responses: aCSF, $26.7 \pm 11.9 \%$; CHPG, $37.7 \pm 18.5 \%)$. This finding also suggests that mGlu5 receptor activation at this agonist dose likely does not produce alcohol-like properties alone.

\section{Discussion}

These results show that mGlu5 receptor activity in the nucleus accumbens is required for the expression of the interoceptive effects of alcohol using drug discrimination procedures. Specifically, we report that systemic pharmacological antagonism of mGlu5, but not mGlu1, receptors blocked the discriminative stimulus effects produced by alcohol ( $1 \mathrm{~g} / \mathrm{kg}$, i.g.). Systemic administration of the mGlu5 receptor antagonist MPEP was found to dramatically inhibit neural activity in the nucleus accumbens core as indexed by c-Fos immunoreactivity. The anatomical specificity of this finding led us to target mGlu5 receptors in the nucleus accumbens core as a potential anatomical substrate of the interoceptive effects of alcohol. Accordingly, microinjection of the mGlu5 receptor antagonist MPEP in the nucleus accumbens core blocked the discriminative stimulus effects of alcohol with an order of potency 160 -fold greater than that observed after systemic administration of the compound. Moreover, pharmacological activation of mGlu5 receptors in the nucleus accumbens core enhanced the discriminative stimulus effects of a low alcohol dose $(0.5 \mathrm{~g} / \mathrm{kg})$, an effect that was blocked by intraaccumbens mGlu5 receptor inhibition, further confirming functional involvement of this receptor system in the expression of the interoceptive effects of alcohol. 

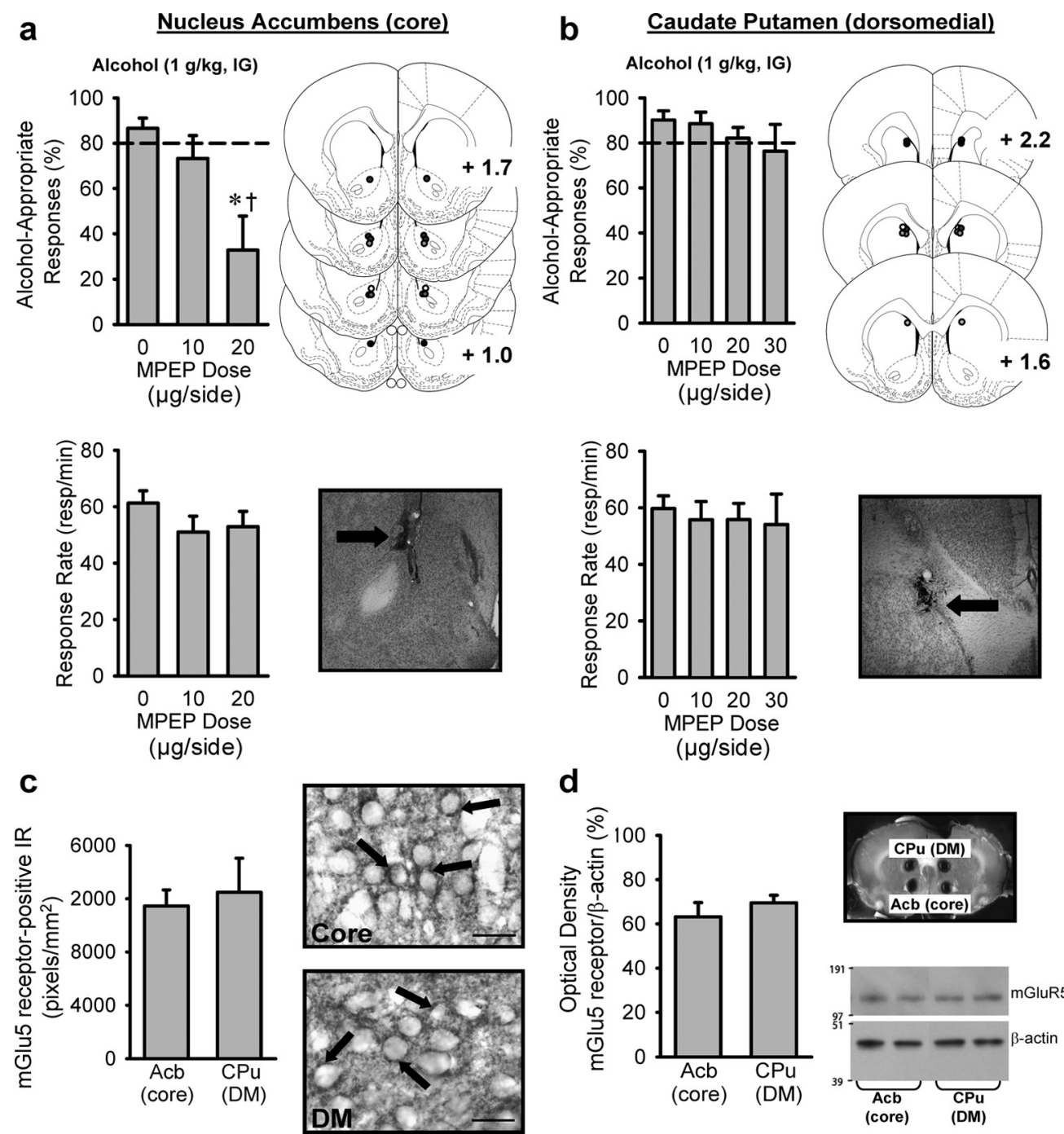

d
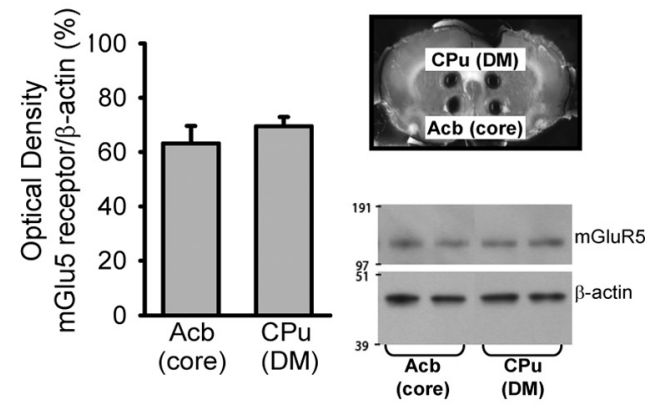

Figure 4. mGlu5 receptor activity in the nucleus accumbens core, but not the dorsomedial caudate-putamen, is required for expression of the interoceptive effects of alcohol (1 $\mathrm{g} / \mathrm{kg}$, i.g.). $\boldsymbol{a}$, Targeted antagonism of mGlu5 receptors in the nucleus accumbens core reduced the discriminative stimulus effects of alcohol $(1 \mathrm{~g} / \mathrm{kg} ; n=8)$, with no effect on response rate. ${ }^{*},{ }^{\dagger} p<0.03$, significant difference from 0 and $10 \mu \mathrm{g}$ of MPEP, respectively (Tukey's test). $\boldsymbol{b}$, Antagonism of mGlu5 receptors in the dorsomedial caudate-putamen did not alter the discriminative stimulus effects of alcohol $(n=8)$ or response rate. Illustrations (right side of each graph) depicting nucleus accumbens (core; $\boldsymbol{a}$ ) and caudate-putamen (dorsomedial; $\boldsymbol{b}$ ); circles illustrate injector placements from individual rats with accurate placements and a corresponding photomicrograph showing an injector tract (arrow). $c$, The nucleus accumbens [Acb (core)] and dorsomedial caudate-putamen [CPu $(D M) ; n=5$ ] showed similar mGlu5 receptor IR. Photomicrographs (100× oil) showing similar cytological expression of mGlu5 receptors in the nucleus accumbens and the dorsomedial caudate-putamen. Arrows identify areas of dense mGlu5 receptor immunoreactivity. Scale bars, $25 \mu \mathrm{m}$. $\boldsymbol{d}$, Western blot analysis confirmed similar mGlu5 receptor expression in the nucleus accumbens and the dorsomedial caudate-putamen $(n=4)$. To the right of the graph is a coronal section of a rat brain showing location of bilateral tissue punches for Western blot analysis and a representative Western blot $(n=2)$ showing similar levels of $\mathrm{mGlu5}$ receptors in the two brain regions. Green and blue bars represent the nucleus accumbens and the caudate, respectively. Values on graphs represent mean \pm SEM.

The group I family (mGlu1 and mGlu5) of mGlu receptors has become a viable target for therapeutic interventions for the treatment of various CNS diseases, including drug abuse. Antagonism of group I receptors, which are predominantly postsynaptic (Shigemoto et al., 1997), has been shown to modulate cocaine, nicotine, and alcohol self-administration and drug-seeking behavior in reinstatement models (Paterson et al., 2003; Tessari et al., 2004; Bespalov et al., 2005; Cowen et al., 2005; Schroeder et al., 2005, 2008; Hodge et al., 2006). Thus, it is critical to evaluate whether the interoceptive effects of alcohol are modulated by these receptors as a possible mechanism(s) that could promote alcohol-seeking and/or alter alcohol self-administration. Results from this study show that systemic administration of the mGlu5 receptor antagonists MPEP or MTEP each inhibited the full expression of the interoceptive effects of alcohol. These findings extend previous work from our laboratory that used a single systemically administered high dose of MPEP (Besheer and Hodge, 2005) by showing that inhibition of the interoceptive effects of alcohol is dose sensitive, specific to the mGlu5 receptor as confirmed by testing MTEP, and selective to the mGlu5 receptor as determined by the evaluation of mGlu1 receptors. Given that mGlu5 receptor antagonism has been shown to reduce alcohol selfadministration (Bäckström et al., 2004; Cowen et al., 2005; Schroeder et al., 2005; Hodge et al., 2006), this raises the possibility that these reductions may be related to an alteration of the interoceptive effects of the self-administered/consumed alcohol. It will be interesting to directly address this possibility in future experiments. Indeed, mGlu5 receptor antagonism has been shown to blunt the discriminative stimulus effects of self-administered alcohol in discrimination-trained rats (Besheer et al., 2006). 

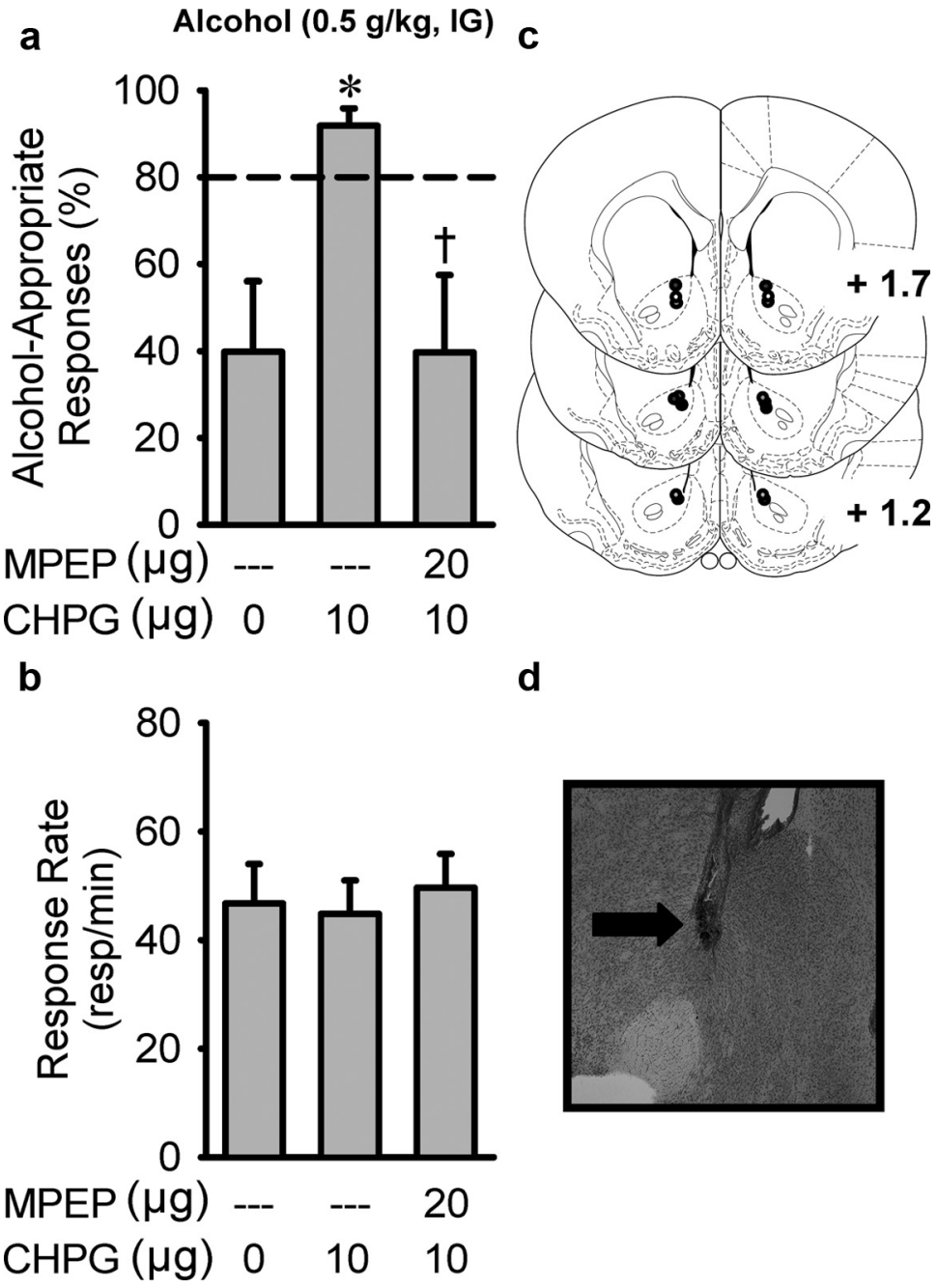

Figure 5. Activation of mGlu5 receptors in the nucleus accumbens core potentiates the interoceptive effects of alcohol. $\boldsymbol{a}$, Targeted activation of $\mathrm{mGlu} 5$ receptors in the nucleus accumbens core by CHPG (10 $\mu \mathrm{g} / \mathrm{side})$ enhanced the discriminative stimulus effects of alcohol $(0.5 \mathrm{~g} / \mathrm{kg}$, i.g.). This enhancement was prevented by intra-accumbens inhibition of $\mathrm{mGlu} 5$ receptors with MPEP (20 $\mu \mathrm{g} / \mathrm{side} ; n=8)$, with no effect on response rate $(\boldsymbol{b}) .{ }^{*} p<0.05$, significant difference from 0 ; ${ }^{\dagger} p<0.05$, significant difference from $10 \mu \mathrm{g}$ of CHPG (Tukey's test). Circles illustrate nucleus accumbens (core) injector placements from individual rats with accurate placements $(\boldsymbol{c})$ and a corresponding photomicrograph showing an injector tract (d; arrow). Values on graphs represent mean \pm SEM.

The present findings are the first to show that systemic antagonism of mGlul receptors does not produce alcohol-like interoceptive effects and do not alter the interoceptive effects produced by alcohol. That is, the reported reductions in alcohol selfadministration after similar manipulation of this receptor system (Lominac et al., 2006; Besheer et al., 2008a,b) most likely are not a result of an alteration to the interoceptive effects of the consumed alcohol. Although the two group I mGlu receptors (mGlu1 and mGlu5) are both located primarily at postsynaptic sites, and share G-protein and cell signaling mechanisms (Gereau and Conn, 1995; Shigemoto et al., 1997), there are important differences between these receptors that may explain the functional dissociation observed in the present study. That is, mGlu5 receptors are highly expressed in the nucleus accumbens (Ferraguti and Shigemoto, 2006), a brain region known to regulate the discriminative stimulus effects of alcohol (Hodge and Cox, 1998; Hodge et al., 2001a; Besheer et al., 2003). In contrast, mGlu1 receptors are densely expressed in the cerebellum (Shigemoto et al., 1992; Fotuhi et al., 1993), in which they have been shown to regulate motor activity and coordination (Ichise et al., 2000). Indeed, motor inhibition (as indicated by decreased response rate) was evident when the antagonist was administered alone and in conjunction with alcohol, consistent with previous findings of motor impairments after mGlul receptor antagonism (Steckler et al., 2005; Besheer et al., 2008a,b). Thus, the functional dissociation between mGlu1 and mGlu5 receptors in the interoceptive effects of alcohol may be related to brain regional receptor expression patterns and the role of these brain regions in complex behavioral processes.

Given the importance of the striatal circuitry in drug reward processes ( $\mathrm{Hy}$ man et al., 2006) and the determined involvement of mGlu5 receptors, but not mGlu1 receptors, in the modulation of the interoceptive effects of alcohol, we hypothesized that striatal mGlu5 receptors might regulate the interoceptive effects of alcohol. The nucleus accumbens core was identified as a potential target given that this region showed significant inhibition in neural activity after mGlu5 receptor antagonism as indexed by quantification of c-Fos immunoreactivity. To our knowledge, this is the first study to show a significant inhibition of neural activity in the nucleus accumbens core after mGlu5 receptor antagonism. Results showed that site-specific pharmacological inhibition of mGlu 5 receptors in the nucleus accumbens core blocked the discriminative stimulus effects of systemically administered alcohol, indicating that intra-accumbens mGlu5 receptor activity is necessary for the full expression of the interoceptive effects of alcohol. Anatomical specificity of function was confirmed by the lack of effect of mGlu5 receptor antagonism in the dorsomedial caudate-putamen and the similar cytological expression patterns and relative density of mGlu5 receptors between the brain regions. Although the dorsomedial caudate is known to regulate stimulus-response relations (Ragozzino, 2007; Tanaka et al., 2008; Balleine et al., 2009), such as those required by the present procedure, the finding that antagonism of mGlu5 receptors in this region did not alter accuracy performance suggests that $\mathrm{mGlu} 5$ receptors within the dorsomedial caudate do not modulate drug-related interoceptive stimulus properties. Indeed, future work will be needed to address this possibility.

Importantly, functional involvement of intra-accumbens mGlu5 receptors in the discriminative stimulus effects of alcohol was further confirmed because activation of mGlu5 receptors in this region enhanced the discriminative stimulus effects of a low alcohol dose $(0.5 \mathrm{~g} / \mathrm{kg})$, which indicates that activity of this receptor system in the nucleus accumbens is sufficient to enhance the interoceptive effects of a subthreshold alcohol dose. Furthermore, this enhancement produced by mGlu5 receptor activation was blocked by intra-accumbens mGlu5 receptor antagonism. 
These data indicate that mGlu5 receptor activity in the nucleus accumbens is both necessary and sufficient for the full expression of the interoceptive effects of alcohol.

The discriminative stimulus effects of alcohol comprise distinct components modulated by different receptor systems. In general, the discriminative stimulus effects of lower doses of alcohol $(1 \mathrm{~g} / \mathrm{kg})$ appear to be mediated by activation of inhibitory $\mathrm{GABA}_{\mathrm{A}}$ receptors, whereas inhibition of excitatory NMDA receptors mediates the discriminative stimulus effects of higher doses of alcohol (2 g/kg) (Grant and Colombo, 1993; Grant, 1999). Given that intra-accumbens antagonism of mGlu5 receptors inhibited the discriminative stimulus effects of a lower dose of alcohol $(1 \mathrm{~g} / \mathrm{kg})$ and activation of mGlu 5 receptors enhanced the discriminative stimulus effects of a low alcohol dose $(0.5$ $\mathrm{g} / \mathrm{kg}$ ), we hypothesize that mGlu5 modulation of the interoceptive effects of alcohol in this brain region may occur through an interaction with the GABAergic component of the alcohol interoceptive cue. This hypothesis is supported in part by evidence showing that $\mathrm{GABA}_{\mathrm{A}}$-positive modulators (i.e., pentobarbital, muscimol) administered into the nucleus accumbens produce alcohol-like properties in animals trained with $1 \mathrm{~g} / \mathrm{kg}$ alcohol (Hodge and Cox, 1998; Hodge et al., 2001a; Besheer et al., 2003). Furthermore, there is evidence for interaction between mGlu5 receptors and GABA systems, because intra-accumbens infusion of the mGlu5 receptor agonist CHPG increases GABA release in the ventral pallidum, an effect that is reversed by the mGlu5 receptor antagonist MPEP (Díaz-Cabiale et al., 2002). Also, perfusion of CHPG into the periaquaductal gray has been shown to enhance extracellular levels of GABA in that region; again, an effect that is reversed by MPEP (de Novellis et al., 2003). Furthermore, anatomical evidence indicates that both $\mathrm{GABA}_{\mathrm{A}}$ and $\mathrm{GABA}_{\mathrm{B}}$ receptors are coexpressed with mGlu5 receptors in the striataopallidal complex (Smith et al., 2000) and that this anatomical distribution may regulate an interaction between mGlu5 and GABA receptors in alcohol discrimination (Besheer et al., 2005). Moreover, it is unlikely that the mGlu5 receptor antagonist effects observed in this study were mediated through NMDA receptors because MPEP has been shown to inhibit NMDA receptor function (O'Leary et al., 2000), which should enhance (Grant and Colombo, 1993; Grant, 1999) rather than inhibit the discriminative stimulus effects of alcohol. Similarly, the CHPGinduced enhancement of the discriminative stimulus effects of alcohol is not likely mediated through NMDA receptors because CHPG has been shown to potentiate NMDA receptor function (Doherty et al., 1997), an effect that would not be predicted to enhance the discriminative stimulus effects of alcohol. However, we predict that a potential interaction between mGlu5 and NMDA receptor systems in modulating the interoceptive effects of alcohol would be more likely with a higher alcohol training dose (i.e., $2 \mathrm{~g} / \mathrm{kg}$ ). Clearly, establishing whether intra-accumbens mGlu5 receptor involvement in the interoceptive effects of alcohol is interacting with the GABAergic or NMDA receptor component will need to be directly assessed in future work.

In conclusion, considerable progress has been made in understanding how mesocorticolimbic systems regulate the motivation to seek natural rewards and addictive drugs (Schultz, 2000; Hyman et al., 2006). Our findings indicate that mGlu5 receptor activity in the nucleus accumbens, a central component of the reward circuitry of the brain, also plays a critical role in the perception of alcohol. Although the specific role of interoceptive drug effects in the contribution to drug use is unknown, there exist several possibilities by which the interoceptive effects may influence drug-seeking and self-administration behavior. For ex- ample, it is possible that the interoceptive cues that accompany drug self-administration come to function as conditioned stimuli that may promote drug-seeking (Wise et al., 2008). In addition, the ability to perceive the characteristic interoceptive properties of a drug may encourage drug-seeking by indicating the effects of sampled substances and, consequently, directing the individual toward one substance rather than another (Stolerman, 1992). Within this framework, the results of the present work suggest that mGlu5 receptors may regulate alcohol self-administration (Bäckström et al., 2004; Cowen et al., 2005; Schroeder et al., 2005; Hodge et al., 2006; Lominac et al., 2006; Cowen et al., 2007; Besheer et al., 2008b) by integrating information about the interoceptive and reinforcing effects of alcohol.

\section{References}

Anderson JJ, Bradbury MJ, Giracello DR, Chapman DF, Holtz G, Roppe J, King C, Cosford ND, Varney MA (2003) In vivo receptor occupancy of mGlu5 receptor antagonists using the novel radioligand $\left[{ }^{3} \mathrm{H}\right] 3$-methoxy5-(pyridin-2-ylethynyl)pyridine). Eur J Pharmacol 473:35-40.

Bäckström P, Hyytiä P (2005) Suppression of alcohol self-administration and cue-induced reinstatement of alcohol seeking by the $\mathrm{mGlu} 2 / 3$ receptor agonist LY379268 and the mGlu8 receptor agonist (S)-3,4-DCPG. Eur J Pharmacol 528:110-118.

Bäckström P, Bachteler D, Koch S, Hyytiä P, Spanagel R (2004) mGluR5 antagonist MPEP reduces ethanol-seeking and relapse behavior. Neuropsychopharmacology 29:921-928.

Balleine BW, Liljeholm M, Ostlund SB (2009) The integrative function of the basal ganglia in instrumental conditioning. Behav Brain Res 199:43-52.

Besheer J, Hodge CW (2005) Pharmacological and anatomical evidence for an interaction between mGluR5- and GABA(A) alphal-containing receptors in the discriminative stimulus effects of ethanol. Neuropsychopharmacology 30:747-757.

Besheer J, Cox AA, Hodge CW (2003) Coregulation of ethanol discrimination by the nucleus accumbens and amygdala. Alcohol Clin Exp Res 27:450-456.

Besheer J, Stevenson RA, Hodge CW (2006) mGlu5 receptors are involved in the discriminative stimulus effects of self-administered ethanol in rats. Eur J Pharmacol 551:71-75.

Besheer J, Faccidomo S, Grondin JJ, Hodge CW (2008a) Effects of mGlu1receptor blockade on ethanol self-administration in inbred alcoholpreferring rats. Alcohol 42:13-20.

Besheer J, Faccidomo S, Grondin JJ, Hodge CW (2008b) Regulation of motivation to self-administer ethanol by mGluR5 in alcohol-preferring $(\mathrm{P})$ rats. Alcohol Clin Exp Res 32:209-221.

Bespalov AY, Dravolina OA, Sukhanov I, Zakharova E, Blokhina E, Zvartau E, Danysz W, van Heeke G, Markou A (2005) Metabotropic glutamate receptor (mGluR5) antagonist MPEP attenuated cue- and scheduleinduced reinstatement of nicotine self-administration behavior in rats. Neuropharmacology 49 [Suppl 1]:167-178.

Bossert JM, Gray SM, Lu L, Shaham Y (2006) Activation of group II metabotropic glutamate receptors in the nucleus accumbens shell attenuates context-induced relapse to heroin seeking. Neuropsychopharmacology 31:2197-2209.

Cosford ND, Roppe J, Tehrani L, Schweiger EJ, Seiders TJ, Chaudary A, Rao S, Varney MA (2003) [ $\left.{ }^{3} \mathrm{H}\right]$-methoxymethyl-MTEP and $\left[{ }^{3} \mathrm{H}\right]$-methoxyPEPy: potent and selective radioligands for the metabotropic glutamate subtype 5 (mGlu5) receptor. Bioorg Med Chem Lett 13:351-354.

Cowen MS, Djouma E, Lawrence AJ (2005) The metabotropic glutamate 5 receptor antagonist 3-[(2-methyl-1,3-thiazol-4-yl)ethynyl]-pyridine reduces ethanol self-administration in multiple strains of alcoholpreferring rats and regulates olfactory glutamatergic systems. J Pharmacol Exp Ther 315:590-600.

Cowen MS, Krstew E, Lawrence AJ (2007) Assessing appetitive and consummatory phases of ethanol self-administration in C57BL/6J mice under operant conditions: regulation by mGlu 5 receptor antagonism. Psychopharmacology (Berl) 190:21-29.

de Novellis V, Marabese I, Palazzo E, Rossi F, Berrino L, Rodella L, Bianchi R, Rossi F, Maione S (2003) Group I metabotropic glutamate receptors modulate glutamate and gamma-aminobutyric acid release in the periaqueductal grey of rats. Eur J Pharmacol 462:73-81. 
Díaz-Cabiale Z, Vivó M, Del Arco A, O’Connor WT, Harte MK, Müller CE, Martínez E, Popoli P, Fuxe K, Ferré S (2002) Metabotropic glutamate mGlu5 receptor-mediated modulation of the ventral striopallidal GABA pathway in rats. Interactions with adenosine $\mathrm{A}(2 \mathrm{~A})$ and dopamine $\mathrm{D}(2)$ receptors. Neurosci Lett 324:154-158.

Doherty AJ, Palmer MJ, Henley JM, Collingridge GL, Jane DE (1997) (RS)2-chloro-5-hydroxyphenylglycine (CHPG) activates mGlu5, but no mGlu1, receptors expressed in $\mathrm{CHO}$ cells and potentiates NMDA responses in the hippocampus. Neuropharmacology 36:265-267.

Ferraguti F, Shigemoto R (2006) Metabotropic glutamate receptors. Cell Tissue Res 326:483-504.

Fotuhi M, Sharp AH, Glatt CE, Hwang PM, von Krosigk M, Snyder SH, Dawson TM (1993) Differential localization of phosphoinositidelinked metabotropic glutamate receptor (mGluR1) and the inositol 1,4,5trisphosphate receptor in rat brain. J Neurosci 13:2001-2012.

Gasparini F, Lingenhöhl K, Stoehr N, Flor PJ, Heinrich M, Vranesic I, Biollaz M, Allgeier H, Heckendorn R, Urwyler S, Varney MA, Johnson EC, Hess SD, Rao SP, Sacaan AI, Santori EM, Veliçelebi G, Kuhn R (1999) 2-Methyl-6-(phenylethynyl)-pyridine (MPEP), a potent, selective and systemically active mGlu5 receptor antagonist. Neuropharmacology 38:1493-1503.

Gereau RW 4th, Conn PJ (1995) Roles of specific metabotropic glutamate receptor subtypes in regulation of hippocampal CA1 pyramidal cell excitability. J Neurophysiol 74:122-129.

Grant KA (1999) Strategies for understanding the pharmacological effects of ethanol with drug discrimination procedures. Pharmacol Biochem Behav 64:261-267.

Grant KA, Colombo G (1993) Pharmacological analysis of the mixed discriminative stimulus effects of ethanol. Alcohol Alcohol [Suppl] 2:445-449.

Grant KA, Knisely JS, Tabakoff B, Barrett JE, Balster RL (1991) Ethanol-like discriminative stimulus effects of non-competitive $N$-methyl-D-aspartate antagonists. Behav Pharmacol 2:87-95

Heilig M, Egli M (2006) Pharmacological treatment of alcohol dependence: target symptoms and target mechanisms. Pharmacol Ther 111:855-876.

Hiltunen AJ, Järbe TU (1989) Discriminative stimulus properties of ethanol: effects of cumulative dosing and Ro 15-4513. Behav Pharmacol $1: 133-140$.

Hodge CW, Cox AA (1998) The discriminative stimulus effects of ethanol are mediated by NMDA and $\operatorname{GABA}(\mathrm{A})$ receptors in specific limbic brain regions. Psychopharmacology (Berl) 139:95-107.

Hodge CW, Nannini MA, Olive MF, Kelley SP, Mehmert KK (2001a) Allopregnanolone and pentobarbital infused into the nucleus accumbens substitute for the discriminative stimulus effects of ethanol. Alcohol Clin Exp Res 25:1441-1447.

Hodge CW, Cox AA, Bratt AM, Camarini R, Iller K, Kelley SP, Mehmert KK, Nannini MA, Olive MF (2001b) The discriminative stimulus properties of self-administered ethanol are mediated by GABA(A) and NMDA receptors in rats. Psychopharmacology (Berl) 154:13-22.

Hodge CW, Miles MF, Sharko AC, Stevenson RA, Hillmann JR, Lepoutre V, Besheer J, Schroeder JP (2006) The mGluR5 antagonist MPEP selectively inhibits the onset and maintenance of ethanol self-administration in C57BL/6J mice. Psychopharmacology (Berl) 183:429-438.

Hyman SE, Malenka RC, Nestler EJ (2006) Neural mechanisms of addiction: the role of reward-related learning and memory. Annu Rev Neurosci 29:565-598.

Ichise T, Kano M, Hashimoto K, Yanagihara D, Nakao K, Shigemoto R, Katsuki M, Aiba A (2000) mGluR1 in cerebellar Purkinje cells essential for long-term depression, synapse elimination, and motor coordination. Science 288:1832-1835

Kelly TH, Emurian CS, Baseheart BJ, Martin CA (1997) Discriminative stimulus effects of alcohol in humans. Drug Alcohol Depend 48:199-207.

Kumaresan V, Yuan M, Yee J, Famous KR, Anderson SM, Schmidt HD, Pierce RC (2009) Metabotropic glutamate receptor 5 (mGluR5) antagonists attenuate cocaine priming- and cue-induced reinstatement of cocaine seeking. Behav Brain Res 202:238-244.

Lavreysen H, Wouters R, Bischoff F, Nóbrega Pereira S, Langlois X, Blokland S, Somers M, Dillen L, Lesage AS (2004) JNJ16259685, a highly potent, selective and systemically active mGlul receptor antagonist. Neuropharmacology 47:961-972.

Lominac KD, Kapasova Z, Hannun RA, Patterson C, Middaugh LD, Szum- linski KK (2006) Behavioral and neurochemical interactions between Group $1 \mathrm{mGluR}$ antagonists and ethanol: potential insight into their antiaddictive properties. Drug Alcohol Depend 85:142-156.

Mathiesen JM, Svendsen N, Bräuner-Osborne H, Thomsen C, Ramirez MT (2003) Positive allosteric modulation of the human metabotropic glutamate receptor 4 (hmGluR4) by SIB-1893 and MPEP. Br J Pharmacol 138:1026-1030.

O'Leary DM, Movsesyan V, Vicini S, Faden AI (2000) Selective mGluR5 antagonists MPEP and SIB-1893 decrease NMDA or glutamate-mediated neuronal toxicity through actions that reflect NMDA receptor antagonism. Br J Pharmacol 131:1429-1437.

Paterson NE, Semenova S, Gasparini F, Markou A (2003) The mGluR5 antagonist MPEP decreased nicotine self-administration in rats and mice. Psychopharmacology (Berl) 167:257-264.

Paxinos G, Watson C (1998) The rat brain in stereotaxic coordinates, Ed 4 London: Academic.

Peters J, Kalivas PW (2006) The group II metabotropic glutamate receptor agonist, LY379268, inhibits both cocaine- and food-seeking behavior in rats. Psychopharmacology (Berl) 186:143-149.

Ragozzino ME (2007) The contribution of the medial prefrontal cortex, orbitofrontal cortex, and dorsomedial striatum to behavioral flexibility. Ann N Y Acad Sci 1121:355-375.

Robbe D, Alonso G, Manzoni OJ (2003) Exogenous and endogenous cannabinoids control synaptic transmission in mice nucleus accumbens. Ann N Y Acad Sci 1003:212-225.

Rodd ZA, McKinzie DL, Bell RL, McQueen VK, Murphy JM, Schoepp DD, McBride WJ (2006) The metabotropic glutamate $2 / 3$ receptor agonist LY404039 reduces alcohol-seeking but not alcohol self-administration in alcohol-preferring (P) rats. Behav Brain Res 171:207-215.

Schroeder JP, Overstreet DH, Hodge CW (2005) The mGluR5 antagonist MPEP decreases operant ethanol self-administration during maintenance and after repeated alcohol deprivations in alcohol-preferring $(\mathrm{P})$ rats. Psychopharmacology (Berl) 179:262-270.

Schroeder JP, Spanos M, Stevenson JR, Besheer J, Salling M, Hodge CW (2008) Cue-induced reinstatement of alcohol-seeking behavior is associated with increased ERK1/2 phosphorylation in specific limbic brain regions: blockade by the mGluR5 antagonist MPEP. Neuropharmacology 55:546-554.

Schultz W (2000) Multiple reward signals in the brain. Nat Rev Neurosci 1:199-207.

Shigemoto R, Nakanishi S, Mizuno N (1992) Distribution of the mRNA for a metabotropic glutamate receptor (mGluR1) in the central nervous system: an in situ hybridization study in adult and developing rat. J Comp Neurol 322:121-135.

Shigemoto R, Kinoshita A, Wada E, Nomura S, Ohishi H, Takada M, Flor PJ, Neki A, Abe T, Nakanishi S, Mizuno N (1997) Differential presynaptic localization of metabotropic glutamate receptor subtypes in the rat hippocampus. J Neurosci 17:7503-7522.

Smith Y, Charara A, Hanson JE, Paquet M, Levey AI (2000) GABA(B) and group I metabotropic glutamate receptors in the striatopallidal complex in primates. J Anat 196:555-576.

Steckler T, Lavreysen H, Oliveira AM, Aerts N, Van Craenendonck H, Prickaerts J, Megens A, Lesage AS (2005) Effects of mGlul receptor blockade on anxiety-related behaviour in the rat lick suppression test. Psychopharmacology (Berl) 179:198-206.

Stolerman I (1992) Drugs of abuse: behavioural principles, methods and terms. Trends Pharmacol Sci 13:170-176.

Stolerman IP, Olufsen KS (2000) Influence of training history on ethanol discrimination in rats. Behav Pharmacol 11:603-612.

Tanaka SC, Balleine BW, O’Doherty JP (2008) Calculating consequences: brain systems that encode the causal effects of actions. J Neurosci 28:6750-6755.

Tessari M, Pilla M, Andreoli M, Hutcheson DM, Heidbreder CA (2004) Antagonism at metabotropic glutamate 5 receptors inhibits nicotine- and cocaine-taking behaviours and prevents nicotine-triggered relapse to nicotine-seeking. Eur J Pharmacol 499:121-133.

Wise RA, Wang B, You ZB (2008) Cocaine serves as a peripheral interoceptive conditioned stimulus for central glutamate and dopamine release. PLoS ONE 3:e2846.

World Health Organization (2004) Global status report on alcohol. Geneva: World Health Organization. 